\title{
A Community-Based Approach to Supply Chain Design
}

The role of beneficiaries in the humanitarian supply chain is highlighted in the imperative to meet their needs but disputed in terms of their actual decision-making and purchasing power. This article discusses the use of a beneficiary-focused, communitybased approach in the case of a post-crisis housing reconstruction programme. In the community-based approach, beneficiaries become active members of the humanitarian supply chain. Implications of this community-based approach are discussed in the light of supply chain design and aid effectiveness.

Keywords: humanitarian supply chain, reconstruction, community-based approach, supply chain design, aid effectiveness

\section{Introduction}

Disasters are increasing in occurrence but most importantly, in their impact on human life and livelihood. Over the last decades, disaster trends show a decrease in deaths but at the same time, an increase in the number of people affected by disasters, as well as an increase of the economic impact of disasters (EM-DAT, 2008). Delivering aid to vulnerable people is at the core of humanitarian logistics, while the economic impact of disasters is to be seen in effects on GDP on the macro level, the livelihood of individuals on the micro level, as well as in terms of the impact of disruptions on any supply chain with organisational members in the disaster area. Not surprisingly, mapping exercises of supply chain risks include political and economic instability as risk sources (e.g. the supply chain risk map by Aon Inc which is the leading global provider of risk management services), and (natural) disasters are seen as operational catastrophes in the supply chain (Norrman and Lindroth, 2001; Christopher and Peck, 2004).

Operational catastrophes are the raison d'être for humanitarian supply chains, which have core competencies in dealing with such disruptions (Kovács and Tatham, 2009b). Thomas and Mizushima (2005, p.60) adapt the Council of Supply Chain Management Professional's definition of logistics management to humanitarian logistics, changing the focus from the end customer to the beneficiary as follows: 
Humanitarian logistics is "the process of planning, implementing and controlling the efficient, cost-effective flow and storage of goods and materials, as well as related information, from point of origin to point of consumption for the purpose of meeting the end beneficiary's requirements”. On the one hand, beneficiaries can be equated with end customers in the humanitarian supply chain (Thomas and Kopczak, 2005; Oloruntoba and Gray, 2006 and 2009; Maon et al., 2009), yet on the other, they lack the purchasing power of customers (Pettit and Taylor, 2007; Kovács and Spens, 2008). Beamon and Kotleba (2006) go as far as to argue that beneficiary preference may be irrelevant in the relief setting. Nonetheless, as its definition suggests, the aim of humanitarian logistics is to meet end beneficiary requirements. Therefore, humanitarian relief operations typically commence with the activities of needs assessment, although, in the absence of good needs assessment data, humanitarian organisations can act as "proxies" for the cumulative needs of beneficiaries and act on their behalf (Tatham, 2009).

At the same time, the role of beneficiaries as "victims" of disasters has been much discussed, including the notion that the term victim indeed victimises beneficiaries (Slim, 2002). A change in perspective was the introduction of the beneficiary view, attributing people not only human rights but a potentially active role, empowering them in the humanitarian context. To date, social marketing to micro-finance have rediscovered the power of beneficiaries, including their decisionmaking and indeed, purchasing power (cf. Andreasen, 1994; Régnier et al., 2008). Yet humanitarian logistics literature has focused to a large extent on humanitarian organisations and their supply chains without considering beneficiaries as playing any active role in these. Even performance measurement in humanitarian logistics has been considered from the point of view of humanitarian organisations (e.g. Schulz and 
Heigh, 2009, van der Laan et al., 2009), or particular programmes and “missions”

(e.g. Beamon and Balcik, 2008), not from the perspective of the beneficiary. The aim of this paper is thus, to examine the benefits and challenges of a beneficiary focus, and in particular, of community-based approaches, for supply chain design in reconstruction. The article commences with a short review of reconstruction supply chains and supply chain design. After a section on research methods, the topics of aid effectiveness and community based approaches in housing reconstruction are reviewed more generally, before turning to the case of housing reconstruction in the Kosovo. The article ends with the implications of community-based approaches in reconstruction for the design of humanitarian supply chains.

\section{Designing supply chains for reconstruction}

Humanitarian supply chain management distinguishes between different areas of activities such as disaster relief in natural and man-made disasters and development aid, as well as between different phases of disaster relief. Humanitarian logistics is associated mostly with the immediate response to a disaster, but there are many activities before and after a disaster that take place in the humanitarian supply chain. As for phases of relief, a minimal distinction is made between preparedness and postdisaster, immediate response phases (Long, 1997; van Wassenhove, 2006), to which Altay and Green (2006) add mitigation and recovery. Further details are added in Safran’s (2003) disaster relief cycle that distinguishes between a disaster and an emergency element within the first post-event, immediate response phase. What is more, Safran (2003) (as well as Pettit and Beresford, 2005) links back reconstruction activities to preparedness in a learning loop. Such learning is particularly important in areas exposed to cyclical disasters such as hurricanes, or regions lying on a tectonic fault, as well as learning from industrial accidents and even (the avoidance of) 
warfare. Reconstruction is the time when housing and infrastructure in the disaster area is rebuilt, people resettled, and includes recovery and rehabilitation. Yet while literature has considered post-disaster prevention since the Indian Ocean tsunami in 2006 (Beresford and Pettit, 2007; Banomyong et al., 2009), research on reconstruction has remained scant (Kovács and Spens, 2008). What is more, reconstruction suffers from a lack of funding, as donors tend to emphasise immediate relief.

An emphasis on the immediate response phase accentuates, if not overaccentuates the need for flexibility and speed in humanitarian supply chains. Yet disaster relief phases are intrinsically interlinked, not only in the activation from preparedness to immediate response (Tatham and Kovács, 2009b) but also from immediate response to reconstruction (Maon et al., 2009), and even from reconstruction to development (Oloruntoba and Gray, 2006). The flux between disaster relief phases implies that supply chain design in reconstruction needs to be flexible to continue from immediate response and to follow to a transition to development aid, as well as to include learning for preparedness. But as opposed to what Oloruntoba and Gray (2006) see as the agility maxim of immediate response, reconstruction operations can be planned (Taylor and Pettit, 2009). The possibility of planning these operations in advance shifts the focus towards cost efficiencies, albeit at the same time, reconstruction supply chains are temporary in nature, although taking a longer term horizon than for the immediate response phase. The temporary aspect also holds for measuring the performance of reconstruction supply chains, which is related to the accomplishment of their mission (cf. Beamon and Balcik, 2008). Yet, as Beamon and Balcik (2008) problematise, amongst other things, the variety, interest and standards of stakeholders make it difficult to measure the 
effectiveness of a humanitarian relief mission. At the same time, accountability to beneficiaries as well as donors highlights the need for performance measurement in humanitarian supply chains. One of the most interesting questions in humanitarian supply chains is how to measure effectiveness, on the level of the organisation, the mission, or aid effectiveness in general. What is more, while there is a call to look at all stakeholders of a "mission”, it is still organisational (or programme) effectiveness that is typically under evaluation (see Schulz and Heigh, 2009, van der Laan et al., 2009). To measure effectiveness in a humanitarian context, the concept needs to be approached from both the beneficiary perspective (not unlike a customer focus in “commercial” supply chain management), from the perspective of the supporting supply chain, as well as from a stakeholder perspective. In this paper, the focus is on the beneficiary perspective on the performance and design of reconstruction supply chains.

\section{Research methods}

This paper is based on the case of the housing reconstruction supply chain in Kosovo, in particular of the Housing Reconstruction Programme of 2000-2001. This supply chain included several organisations, the European Agency for Reconstruction (EAR), its 20 NGO implementing partners, 14 material suppliers, technical inspection teams, procurement specialists and constructors on the one hand, other donors and the United Nations Interim Administration Mission in Kosovo (UNMIK) on the other hand, and a number of housing committees on different levels to administer the housing reconstruction programme. UNMIK was instrumental in setting up a central housing committee as well as municipal housing committees, which ran in parallel to village reconstruction committees in relation to NGO implementing partners. Importantly, village reconstruction committees were composed of representatives of village 
communities, including potential beneficiaries. The housing reconstruction programme thus followed a community-based approach, and the supply chain included beneficiaries as active members of the reconstruction supply chain. Figure 1 depicts the organisational structure of the Housing Reconstruction Programme. It compares well to Oloruntoba and Gray’s (2006) “typical humanitarian supply chain” that consists of donors and governments, international agencies (here the European Agency for Reconstruction and UNMIK's Central Housing Committee), international and local NGOs (here as implementing partners), community-based organisations (Municipal Housing Committees and Village Reconstruction Committees/VRC) in terms of local partners and beneficiaries (beneficiary households), while adding technical inspection, purchasing agencies, and material suppliers as supply chain members.

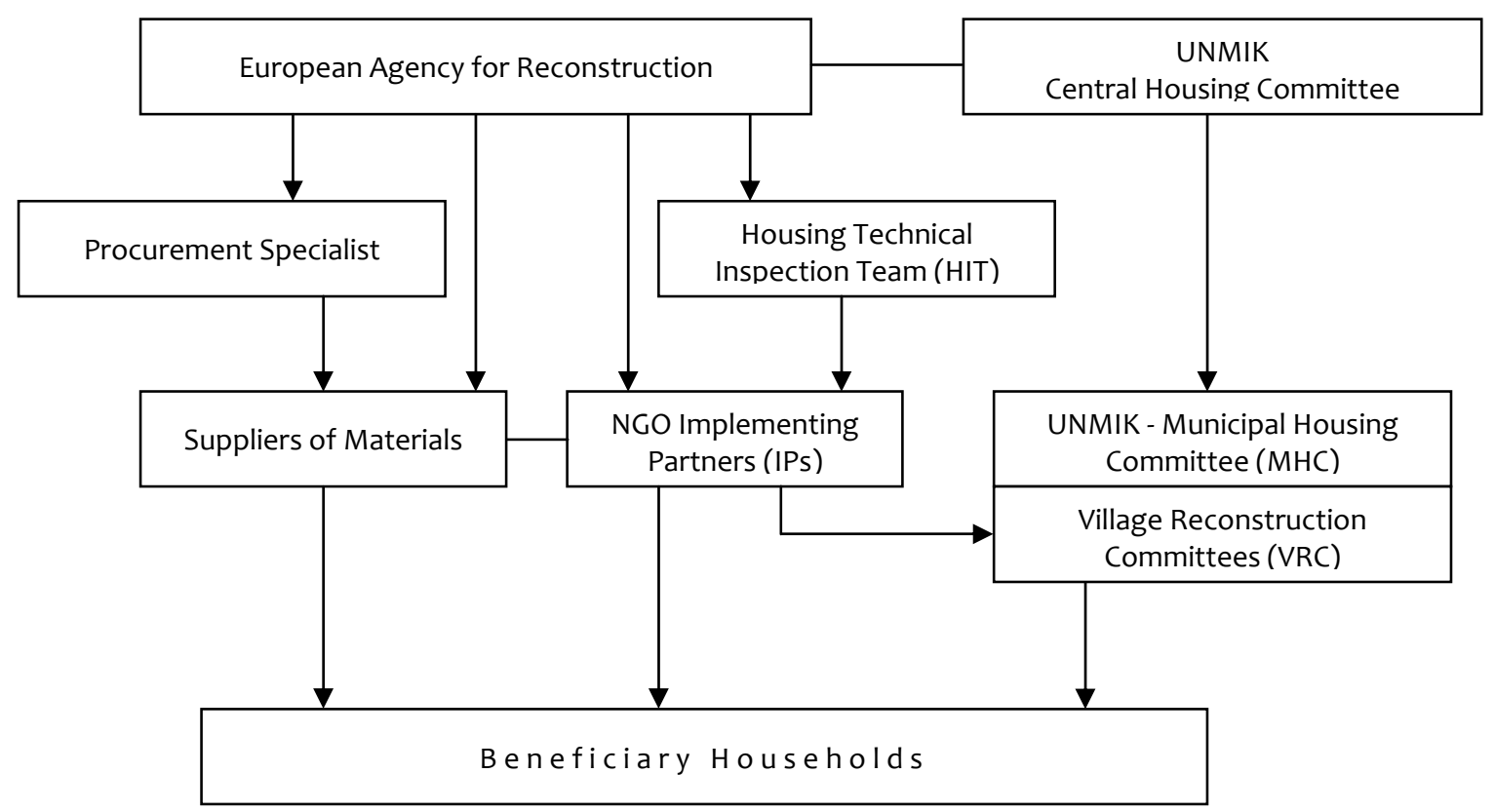

Figure 1. The entities that were involved in the Kosovo housing reconstruction supply chain (Source: EAR, 2002).

This article is based on secondary data analysis of data collected for an internal review of the EAR's Housing Reconstruction Programme in Kosovo. This internal 
evaluation (results of which were reported in EAR, 2002) thus serves as the main data source of the study, though it needs to be mentioned that a member of the research team was also involved in the EAR evaluation itself. Whilst this increases the access and understanding of the data, one of the shortcomings of secondary data analysis remains, that of the data collection serving a different purpose than in this study. Nonetheless the value of the data lies in three things: a) the magnitude and the importance of the reconstruction project (huge economic and human resources were deployed) which was also very much interrelated to the peace-building process b) the uncertainty in the region due to political, cultural and ethnic considerations, c) the role of local communities in the design and implementation of disaster relief efforts. Secondary data analysis was employed as a research strategy in this paper due to the major practical constraints in accessing the research object.

Secondary data analysis is quite common in other fields of research such as public health (see e.g. Pati and Danagoulian, 2008; Yam et al., 2009) and housing development (e.g. Tesfaye, 2007), and Internet research (e.g. Nancarrow et al., 2001). In logistics and supply chain management, secondary data analysis is mostly used for complementing primary data, though research in areas such as supply chain performance (Cuthberson and Piotrowicz, 2008), modelling the bullwhip effect (Lee et al., 1997) and estimating transaction costs in supply chains (Hobbs, 1996) also makes use of secondary data analysis as a sole method. Several articles in humanitarian logistics are also based on secondary data analysis (e.g. Pardasani, 2006; Beresford and Pettit, 2007) as this method allows for the analyses of events in what would otherwise be inaccessible settings, due to practical weaknesses in accessing the research object (cf. Wang et al., 1992). Interestingly, logistics and supply chain 
management research has also been criticised for a lack of innovative applications of secondary data (Sachan and Datta, 2005).

In the original EAR review, case study data were collected from the members of the reconstruction supply chain as listed above, including a random sample of village committees, in in-depth interviews. This data was complemented with a mail survey sent to other NGOs in the area (of which 12/20 were returned). The small number of responses has not been seen as a problem considering the small sample size (20) and the abundance of open-ended questions in the survey, which gathered qualitative data rather than numerical assessments. Considering a potential bias in village reconstruction committees that made approval decisions as well as represented beneficiaries, these data were complemented (and triangulated) with focus group interviews in Gjergjice. Beneficiary data were captured via a (quantitative) household survey on a random sample of 720 actual beneficiaries plus a control group of 100 people whose application for housing reconstruction had been rejected in the programme. The latter, rather descriptive, survey looked at the satisfaction of beneficiaries with the housing reconstruction programme and its implementation.

\section{Aid effectiveness in housing reconstruction}

There is an ongoing debate whether supply chain performance in disaster relief should be measured (a) internally related to the efficiency and effectiveness of the supply chain of any particular humanitarian organisation, (b) in the humanitarian aid supply network, i.e. taking the co-ordination of relief activities across several humanitarian organisations into account, or (c) externally, looking at aid effectiveness en large. Aid effectiveness is usually approached from a macro-economic perspective, as to say, in terms of the effects of aid on living standards and the stimulation of economic growth (Doucouliagos and Paldam, 2005). However, from the perspective of humanitarian 
supply chains, aid effectiveness can be seen as a measure of customer service, i.e. incorporating the beneficiary view to assessing supply chain performance. Oloruntoba and Gray (2009) even introduce the notion of customer relationship management in humanitarian supply chains. Parallels can be drawn to taking a patient view on health care supply chains (e.g. Spens and Bask, 2002; Swinehart and Smith, 2005). This is to evaluate the effectiveness of a 'mission' or programme (Beamon and Balcik, 2008). What is more, humanitarian supply chains need to be designed in order to support this mission.

Equitable aid distribution targets the most vulnerable people without discrimination and according to their needs. The equity consideration is a distinguishing aspect of decision-making in the non-profit and public sectors (Balcik et al., forthcoming). The needs of beneficiaries, in essence, demand in the reconstruction supply chain, can be related to the impact of the disaster on their livelihoods (in housing reconstruction the damage to their homes) but also to their resources and abilities to restore these livelihoods. Needs assessment is a critical activity in any humanitarian supply chain, though in absence of actual needs data, humanitarian organisations often act as "proxies” to quantify the needs of a population (Tatham, 2009). Considering the relatively long-term perspective of reconstruction, there is usually no need for humanitarian organisations to act as such proxies in this phase of relief, rather, this is a situation in which beneficiaries can indeed articulate their needs. Although demand is not created in the sense of purchasing power - considering that needs are constituted by a lack of resources beneficiaries can indeed become active members of the reconstruction supply chain. Yet, whilst technical inspection teams can assess damage to buildings, the assessment of the resources and abilities of beneficiaries is more difficult. Equitable aid 
distribution is not seen as a problem not a problem if aid, and funding, are unlimited. Constraints to funding, however, impose the requirement to find and assist the most vulnerable beneficiaries in order to improve living standards overall. What is more, equity is related to fairness, justice and impartiality, hence equity decisions require judgments regarding how individuals are affected by critical decisions (Balcik et al., forthcoming). For example, tensions in post-conflict situations have to be mitigated to ensure equity in aid in terms of assistance without discrimination.

Another aspect of aid effectiveness is the contribution to economic growth (Doucouliagos and Paldam, 2005). Local sourcing, where possible, has a positive impact on the economic situation in the region, as well as ensures the cultural and regional applicability of solutions and the potential to maintain local lifestyles (cf. Long and Wood, 1995). Furthermore, the use of local information, expertise and labour contributes to local leaders taking a personal interest in the success of operations (Long and Wood, 1995). Not surprisingly, thus, there is a trend towards local sourcing in humanitarian supply chains (Jahre and Spens, 2007). When it comes to reconstruction, local knowledge is important in assessing meteorological conditions of the region, potential natural hazards (Pande and Pande, 2007) as well as local building codes and customs (Pardasani, 2006).

\section{A community based approach to housing reconstruction}

The view on aid recipients has changed throughout past decades. An earlier, victim view, would not only victimise aid recipients (Slim, 2002) but also assign them a passive role in the supply chain. In this view the needs of beneficiaries are not seen to be important, and the humanitarian community (donors and humanitarian organisations) provides assistance as they themselves assume to fit best. Many humanitarian organisations have a vast experience on previous needs and priorities of 
beneficiaries that can be used also for the prepositioning of prioritised items such as water purification tablets, high protein biscuits, shelter equipment etc. in different regions. Previous experience thus contributes positively to disaster preparedness and thus, to the mobilisation of disaster relief (Kovács and Tatham, 2009b). Not surprisingly, this poses the question of "who is the customer" in the humanitarian supply chain (Oloruntoba and Gray, 2009). Even the assessment of beneficiary needs can be performed without actual beneficiary participation through e.g. the use of unmanned aerial vehicles, thus shortening lead times in disaster relief (Tatham, 2009). Initial needs assessments can also be assembled through partner organisations and third party information (McLachlin et al., 2010).

This perspective has though, been challenged in several ways. Beneficiaries are no longer seen as passive people whose livelihood happened to be affected by a disaster. Needs assessment activities have been altered to actively seek information from beneficiaries as they themselves articulate their needs (e.g. through the use of Red Cross/Red Crescent FAC teams in disaster areas). Whilst this has led to an empowerment of beneficiaries, the "voice" of the beneficiary being heard from the very beginning (cf. McCorkindale, 1994), it leads to new challenges in humanitarian logistics, e.g. to questions of sampling, visiting of the same households, whose voice should be heard etc. Needs are then matched with supplies. More recently, the push thinking of donors and suppliers has also been challenged (Oloruntoba and Gray, 2009), and is starting to be replaced with pull thinking that originates from needs assessment.

Needs assessment is, however, not the only aspect of "active” beneficiaries. Whilst for a long time, beneficiaries were seen as deprived of their purchasing power (cf. Pettit and Taylor, 2007; Kovács and Spens, 2008), recently, humanitarian aid has 
embraced cash components in aid as well as micro-financing for development. As early as in 1998, the IFRC handed out a cash component to beneficiaries in the response to Hurricane Mitch. Direct cash donations to beneficiaries have several advantages. Firstly, they restore the purchasing power of the beneficiary and give her/him the opportunity to decide actively on their most urgent needs. Secondly, from a supply chain perspective, it reduces the need for all sorts of logistical activities from purchasing to transportation to last mile distribution. Thirdly, they do not undermine the local economy with a sudden rise in imports. For obvious reasons, cash components in aid are viable only if the desired supplies for beneficiaries exist in the marketplace.

Beneficiaries can not only be activated to decide upon their own individual needs, but also as a community. The community-based approach is a so-called grassroot approach with an aspect of self-organisation of beneficiaries. Communities can be activated for the supply of materials and labour as well as in decision-making. Such an approach is more likely to ensure a precise articulation of needs, as well as beneficiary participation and empowerment (Pardasani, 2006). What is more, a community-based approach can contribute local knowledge to a reconstruction programme.

\section{Housing reconstruction in the Kosovo}

The disaster that necessitated the housing reconstruction programme in the Kosovo was a man-made humanitarian crisis in the late 1990s. Indeed, about $97 \%$ of disasters are man-made such as terrorist attacks, coupe d'états, as well as political and refugee crises (van Wassenhove, 2006). Signs of an upcoming crisis in the Kosovo appeared well before the actual conflict and war. The international community including aid agencies and humanitarian non-governmental organisations (NGOs) had a long time 
to prepare for its aftermath. The end of the conflict revealed large-scale housing destruction: an estimated 120,000 houses out of a total of over 250,000 were damaged or destroyed, although to different degrees. Houses were classified as very seriously damaged if over $60 \%$ of the house was destroyed, which in most cases meant effective destruction without even a sound foundation remaining. 47,000 houses pertained to this category. A further 32,000 houses were seriously damaged (i.e. 41$60 \%$ of the house damaged), and 41,000 less badly damaged. The EAR had the possibility to provide reconstruction support for about only 12,000 houses. This constraint called for an approach to select beneficiaries that would be targeted in the housing reconstruction programme. The principles of humanitarianism include alleviating human suffering wherever found, without discrimination, and in relation to need (cf. Tomasini and van Wassenhove, 2009). Equitable distribution of aid thus is based on the actual needs of beneficiaries. As to say, demand for housing reconstruction assistance was to be determined not only by damages caused to the housing but also by the existing resources of beneficiaries to restore their homes.

On the supply side, the damage assessment of the International Management Group (IMG) revealed some problems in the supply of building materials. Embargos, closed borders and delays in deliveries caused problems with the import of materials. At the same time, there was a limited availability of building materials such as timber and roof tiling within the Kosovo. A contributing factor to the scarcity of timber was the potential ecological impact of procuring timber from within the country only.

Several factors contributed to the urgency of housing reconstruction. Apart from the question of a return to normal life and away from temporary housing, the end of the war saw a large wave of returnees. UNHCR estimated a total of 100,000 returnees until the end of 2000, mostly Kosovo Albanian refugees returning home. 
Problems related to property rights appeared as well as the danger of further, renewed tensions between population groups. In other words, while demand is rather predictable in reconstruction, reconstruction supply chains that deal with post-military conflicts need to take the potential of renewed hostilities into account (Taylor and Pettit, 2009).

\section{Ensuring equity in aid distribution in the Kosovo}

Given a scarcity of funds for housing reconstruction, the Housing Programme needed to establish criteria for the selection of the beneficiaries most in need of their assistance. Anderson and Woodrow’s (1998) Capacities and Vulnerability Analysis was employed to match people, vulnerabilities and their capacities with the programme. This analysis is based on a matrix that evaluates the vulnerabilities as well as capacities of beneficiaries in three dimensions: the physical/material, social/organisational, and motivational/attitudinal. As a result of this analysis, most vulnerable households were deemed the ones least able to access the necessary resources to rebuild. From a macro-economic perspective, such a social targeting approach is applicable where the aim is to improve overall living conditions.

Different organisations were involved in the identification of the most vulnerable households. Implementing partners of NGOs brought in international as well as local social assessment experts to carry out the capacities and vulnerability analysis. Yet the identification of beneficiaries started at the village level. Local partners in the form of community-based organisations that link implementing NGOs to beneficiaries are typical for humanitarian supply chains (Oloruntoba and Gray, 2006). In this case, village reconstruction committees were formed through a bottomup approach, their members elected from and by the community, implementing a community-based approach. The aim of village reconstruction committees was to 
ensure the transparency of the beneficiary selection process, rendered accountability to both selected and non-selected beneficiaries and informed the community about the Housing Reconstruction Programme. This approach did indeed ensure beneficiary participation in the Housing Reconstruction Programme, even if not ultimately selected for assistance.

Two methods were employed to mitigate potential post-conflict tensions. Firstly, information from the village reconstruction committees was triangulated with visible disposable assets and general living conditions to judge the income/asset situation of beneficiaries. These were assessed by the social assessors of implementing partners (NGOs). Other data used were technical damage assessments and the social vulnerability of single-headed households and widows. Upon the triangulation, municipal housing committees still verified the proposed beneficiary families. The second method was to open several potential channels to apply for assistance with housing reconstruction. Applications could be delivered to village reconstruction committees, or directly to UNMIK's municipal or central housing committees. Over $50 \%$ of applications were, sent to village reconstruction committees (which represented $56 \%$ of the selected and $48 \%$ of rejected applications), which can be seen as an acceptable legitimacy for such a community-based approach.

Findings from both the NGO survey and the beneficiary household survey also support the legitimacy of this approach. Interestingly, not only $82 \%$ of the actual beneficiaries of the Housing Reconstruction Programme, but also 30\% of rejected applicants rated the VRC as satisfactory. Applications rejected by the VRC could still be sent to other instances directly, i.e. handled by UNMIK's municipal or central housing committees, but the positive rating of VRCs by rejected applicants indicates that the community base of VRCs indeed made the process more transparent and 
acceptable to beneficiaries. This finding shows that community-based approaches and social targeting in beneficiary selection not only ensure local participation in reconstruction, but also have a positive effect on beneficiary satisfaction. Such a community-based approach builds on beneficiaries becoming active members of the supply chain. Village reconstruction committees are composed entirely of beneficiaries and act as gatekeepers of aid. This does not imply that the community had the final word in selection. On the contrary, it was the IP that played the major role in selecting the "right” beneficiaries after crosschecking the information supplied by the VRC.

\section{Beneficiaries as active members of the reconstruction supply chain}

From the perspective of the humanitarian supply chain, such a community-based approach to reconstruction also ensured access to local suppliers and capacities. This is in line with Long and Wood (1995)'s and McLachlin et al. (2010)'s suggestion to base the humanitarian supply chain on local expertise in terms of information from local personnel and a local labour force. A community based approach contributes to the maintenance of local lifestyles as well as the engagement of local leaders who take an interest in the success of operations. What is more, the hiring of local staff and the purchasing of local materials and services contributes positively to local economic development and thus, aid effectiveness from a macro-economic perspective as well.

The implementing partners (IPs) of the Housing Reconstruction Programme adopted a community-based approach also in the selection of construction labour techniques of self-help, assisted self-help, and contractors (see Table 1). These could be mixed, so for example a nominally self-help house could have a contractor for the roof. Assisted self-help could comprise unpaid village labour teams as well as the 
more typical paid mobile teams of craftspeople. Table 1 summarises the strengths and weaknesses of each of these construction techniques as perceived by the beneficiaries.

Table 1. Beneficiary participation in reconstruction (Source: EAR, 2002)

\begin{tabular}{|c|c|c|}
\hline $\begin{array}{c}\text { Labour } \\
\text { assistance }\end{array}$ & Strengths & Weaknesses \\
\hline Self-help & $\begin{array}{l}\text { - Encourages beneficiary } \\
\text { participation/ownership } \\
\text { - Generates local income and } \\
\text { maximises involvement of local } \\
\text { labour } \\
\text { - Moderates envy of non-selected } \\
\text { neighbours } \\
\text { - Cost-efficient }\end{array}$ & $\begin{array}{l}\text { - The most vulnerable families } \\
\text { cannot benefit from the self-help } \\
\text { approach because of lack of } \\
\text { expertise and economic means } \\
\text { - Need for more supervision by IP } \\
\text { (not enough while needed) } \\
\text { - More time-consuming }\end{array}$ \\
\hline $\begin{array}{l}\text { Assisted } \\
\text { self-help }\end{array}$ & $\begin{array}{l}\text { - Encourages beneficiary } \\
\text { participation/ownership } \\
\text { - Ensures a more timely delivery if } \\
\text { used to supplement “slow” } \\
\text { beneficiaries }\end{array}$ & $\begin{array}{l}\text { - Higher pressure for timely } \\
\text { delivery of material } \\
\text { - More supervision (i.e. clarifying } \\
\text { all of the obligations the } \\
\text { beneficiaries have to meet in } \\
\text { order to be problem-free and to } \\
\text { finish on time) }\end{array}$ \\
\hline Contractors & $\begin{array}{l}\text { - The only feasible approach for } \\
\text { the most vulnerable } \\
\text { - Time-efficient } \\
\text { - Quality control }\end{array}$ & $\begin{array}{l}\text { - Higher costs (i.e. fewer houses } \\
\text { possible within the same overall } \\
\text { budget) }\end{array}$ \\
\hline
\end{tabular}

Implementing partners had the flexibility to decide which method was the most appropriate in the individual case. Some implementing partners adopted direct financial assistance to the beneficiaries in order to utilise the skilled labour present within the assisted family (extended) or the community and, as a means of ensuring that the cash flow was absorbed by the local economy. This cash component of aid also contributed to the empowerment of beneficiaries in them regaining their purchasing power. 
Whilst it was possible to use local labour and contractors, local sourcing of construction materials proved more difficult. The existing market in Kosovo could not cope with the rapidly increasing demand for construction materials. Therefore, most of the building materials had to be imported. For example, Kosovo did not have a functioning brick factory hence bricks were imported. Timber also needed to be imported from Bulgaria. The resulting estimate of local input, mostly of sand and gravel, sets its rate of housing materials at $25 \%$.

The supply chain design of the Housing Reconstruction Programme changed over time. At the beginning, materials were centrally procured through an agent contracted directly by the donor, and the agents subcontracted suppliers. In the later phases of the programme, materials supply was organised through international open tenders for each municipality. Contracted material suppliers were also in charge of all logistical activities including last mile deliveries and inventory management. Implementing partners employed, however, a controller for warehouses, while procurement specialist teams were responsible for quality control.

The main challenge in the supply of housing materials was delays in deliveries. These were caused by a lack of experience of suppliers in trading with housing materials, as well as by the sheer scale of the Housing Reconstruction Programme. Further delays were instigated by the closing of the Former Yugoslav Republic of Macedonia border and the prior destabilisation of transport infrastructure such as railways. The main problem, however, remained the scarcity of supply of housing materials facing such a surge in demand. Local suppliers also experienced cash flow problems as no payment in advance was allowed. This led to the introduction of a voucher system in 2000. Beneficiary households were given vouchers (value corresponding to the assessed damage category) to be exchanged for 
specified reconstruction materials at nominated supply locations, whether these are private trader's premises, or warehouses managed by implementing partners.

Emphasis was placed on flexibility and maximum control of the beneficiaries, though suppliers were pre-selected by the reconstruction agency (EAR). Thus, the voucher system again stressed the active role of beneficiaries in the housing reconstruction supply chain. Indeed, $90.4 \%$ of beneficiaries expressed their satisfaction with the voucher system.

\section{Conclusions}

Similar to other humanitarian crises the need for co-ordinated action in the Kosovo was undisputable, since effective reconstruction efforts require combined action among different international organisations. In addition to this, the paper revealed clearly the crucial role that beneficiaries may play which can go beyond the articulation of their needs to the design, but also the actual implementation of the redevelopment efforts. Their involvement and contribution in the case of the Kosovo Housing Reconstruction Programme was not limited in the identification of the most vulnerable beneficiaries. Instead, beneficiaries provided labour as well as, to some extent, materials, while they were also actively involved in the selection and implementation of the programme.

\section{Benefits from community involvement}

The active participation of the community in the Kosovo housing reconstruction efforts seems to be accompanied by a number of benefits. First of all, community's involvement in the selection of beneficiaries resulted in increased transparency. Next, the use of local sourcing in humanitarian aid, in contrast to other cases (e.g. the 2006 Java earthquake and tsunami where the use of local bamboo as a standard material affected the speed of delivery and the rate of utilisation) has resulted in positive 
effects on local economies. Local sourcing implies a move away from global purchasing towards local and regional sourcing that takes also the lifestyles and cultures of beneficiaries into account (Long and Wood, 1995). This is not to say that materials cannot be purchased in a global market, but before taking such a decision the potential impact on the local economy, local customs, and even the applicability of the solutions provided has to be taken into consideration.

A community-based approach to reconstruction ensures the motivation of beneficiaries to participate in the programme - and ensures the timely completion of reconstruction. Moreover, local participation in reconstruction through labour and materials leads to cost efficiencies as locally available materials do not need to be imported, and transportation costs are relatively low. Local labour is also more cost efficient compared to salaries of expatriates contracted for reconstruction.

\section{Challenges in implementing a community based approach}

The active role of beneficiaries in reconstruction can be facilitated if the reconstruction supply chain is designed around them. As the Kosovo Housing Reconstruction Programme indicates, beneficiaries and communities do have important roles to play, but final decision making should be left to IPs. IPs have to be as objective as possible and to avoid manipulation by local communities. Another important issue that emerged from the Kosovo case was the need to include all ethnic minorities in the Housing Reconstruction Programme so as to ensure that the accessible minority population receives its fair share.

Within the area of humanitarian aid, reconstruction supply chains seem to benefit from a community-based approach despite the potential risks. Much of the effectiveness of reconstruction supply chains depends thus on community 
involvement in beneficiary selection as well as in the implementation of reconstruction programmes.

Embracing a community-based approach requires a dynamic view on supply chain design. Whilst reconstruction does not need the proxy function of humanitarian organisations, the identification and selection of implementing partners and material suppliers requires some time. Pre-identifying potential implementing partners and material suppliers would help in the quick establishment of decision-making organs such as village reconstruction committees in this case. As often in humanitarian logistics, preparedness is key to the effectiveness of aid distribution also in relationship-building.

\section{References}

Altay, N. and Green, W. (2006), OR/MS research in disaster operations management. European Journal of Operational Research, Vol. 175 No.1, pp. 475-493.

Anderson, M.B. and Woodrow, P.J. (1998), Rising from the Ashes. Development Strategies in Times of Disaster, Lynne Rienner Publishers, Boulder, Colorado.

Andreasen, A.R. (1994), "Social marketing: its definition and domain”, Journal of Public Policy and Marketing, Vol.13 No.1, pp.108-114.

Balcik, B., Iravani, S. and Smilowitz, K. (forthcoming), “A review of equity in nonprofit and public sector: a vehicle routing perspective”, In: Cochran, J.J. (ed.), Wiley Encyclopedia of Operations Research and Management Science, John Wiley \& Sons, 2010.

Banomyong, R., Beresford, A. and Pettit, S. (2009), “Logistics relief response model: the case of Thailand's tsunami affected area”, International Journal of Services Technology and Management, Vol.12 No.4, pp.414-429.

Beamon, B. and Balcik, B. (2008), "Performance measurement in humanitarian relief chains”, International Journal of Public Sector Management, Vol.21 No.1, pp. 4-25.

Beamon, B. and Kotleba, S. (2006), "Inventory management support systems for emergency humanitarian relief operations in South Sudan", International Journal of Logistics Management, Vol.17 No.2, pp.187-212.

Beresford, A. and Pettit, S. (2007), "Disaster management and mitigation: A case study of logistics problems in Thailand following the Asian Tsunami”, In: Halldórsson, Á. and Stefánsson, G. (eds.): Proceedings of the $19^{\text {th }}$ Annual Conference for Nordic Researchers in Logistics, NOFOMA 2007, Reykjavík, Iceland, pp.121-136.

de Brito, M., van der Laan, E. and Vergunst, D. (2007), "Humanitarian organisations and performance measurement”, In: Tatham, P. (ed.): CD-ROM Proceedings of the International Humanitarian Logistics Symposium, Faringdon, UK 
Christopher, M. and Peck, H. (2004), “The Five Principles of Supply Chain Resilience,” Logistics Europe, Vol. 12 No. 1, pp. 16-21.

Cuthberson, R. and Piotrowicz, W. (2008), "Supply chain best practices identification and categorisation of measures and benefits", International Journal of Productivity and Performance Measurement, Vol.57 No.5, pp.389404.

Doucouliagos, H. and Paldam, M. (2005), "The aid effectiveness literature. The sad result of 40 years of research”, Working Paper No.2005-15, University of Aarhus, Denmark.

EAR (2002), “Kosovo Housing Reconstruction Programme 2000-2001”, Evaluation Report, Programming, Coordination and Evaluation Division Evaluation Unit, September 2002.

EM-DAT (2008), “Emergency Events Database”, Université Catholique de Louvain, available at: www.emdat.be/Database/terms.html (accessed 29 Jan 2009).

Hobbs, J.E. (1996), “A transaction cost approach to supply chain management”, Supply Chain Management: An International Journal, Vol.1 No.2, pp.15-27.

Jahre, M. and Spens, K. (2007), “Buy global or go local - that's the question”, in Tatham, P. (ed.): CD-ROM Proceedings of the International Humanitarian Logistics Symposium, Faringdon, UK.

Kovács, G. and Spens, K. M. (2007), "Humanitarian logistics in disaster relief operations”, International Journal of Physical Distribution and Logistics Management, Vol.37, No.2, pp.99-114.

Kovács, G. and Spens, K. (2008), “Chapter 13: Humanitarian logistics revisited”, in Arlbjørn, J.S., Halldórsson, Á, Jahre, M. and Spens, K. (eds.): Northern Lights in Logistics and Supply Chain Management, CBS Press, Copenhagen, Denmark, pp.217-232.

Kovács, G. and Tatham, P. (2009), "Humanitarian logistics performance in the light of gender", International Journal of Productivity and Performance Management, Vol.58 No.2, pp.174-187.

Kovács, G. and Tatham, P. (2009b), "Responding to disruptions in the supply network - from dormant to action.” Journal of Business Logistics, Vol.30 No.2, pp.215-229.

Lee, H.L., Padhmanabhan, V. and Whang, S. (1997), “The bullwhip effect in supply chains”, Sloan Management Review, Vol.38 No.3, pp.93-102.

Long, D. (1997), "Logistics for disaster relief”, IIE Solutions, Vol.29 No.6, pp.26-29.

Long, D.C. and Wood, D.F. (1995), “The logistics of famine relief”, Journal of Business Logistics, Vol.16 No.1, pp.213-227.

Maon, F., Lindgreen, A. and Vanhamme, J. (2009), “Developing supply chains in disaster relief operations through cross-sector socially oriented collaborations”, Supply Chain Management: An International Journal, Vol.14 No.2, pp.149-164.

McCorkindale, L. (1994), “Food aid: human right or weapon of war?”, British Food Journal, Vol.96 No.3, pp.5-11.

McLachlin, R., Larson, P.D. and Khan, S. (2010), "Not-for-profit supply chains in interrupted environments”, Management Research News, Vol.32 No.11, pp.1050-1064.

Norrman, A. and Lindroth, R. (2001), "Supply Chain Risks and Risk Sharing Instruments-An Illustration from the Telecommunication Industry," in McKinnon, A. (ed.), Proceedings of the 6th Annual Logistics Research Network Conference, Edinburgh, UK, pp. 297-307. 
Oloruntoba, R. and Gray, R. (2006), “Humanitarian aid: an agile supply chain?” Supply Chain Management: An International Journal, Vol.11 No.2, pp.115120.

Oloruntoba, R. and Gray, R. (2009), "Customer service in emergency relief chains", International Journal of Physical Distribution and Logistics Management, Vol.39 No.6, pp.486-505.

Owusu, R.A. (2002), "Project marketing to Africa: lessons from the case of IVO Transmission Engineering and Ghana’s national electrification scheme”, Journal of Business and Industrial Marketing, Vol.17 No.6, pp.523-537.

Nancarrow, C., Pallister, J. and Brace, I. (2001), “A new research medium, new research populations and seven deadly sins for Internet researchers", Qualitative Market Research: An International Journal, Vol.4 No.3, pp.136149.

Pande, R.K. and Pande, R. (2007), "Resettlement and rehabilitation issues in Uttaranchal (India) with reference to natural disasters”, Disaster Prevention and Management, Vol.16 No.3, pp.361-369.

Pardasani, M. (2006), "Tsunami reconstruction and redevelopment in the Maldives. A case study of community participation and social action”, Disaster Prevention and Management, Vol.15 No.1, pp.79-91.

Pati, S. and Danagoulian, S. (2008), "Immigrant children's reliance on public health insurance in the wake of immigration reform”, American Journal of Public Health, Vol.98 No.11, pp.2004-2010.

Pettit, S.J. and Beresford, A.K.C. (2006), "Emergency relief logistics: An evaluation of military, non-military, and composite response models”, International Journal of Logistics: Research and Applications, Vol.8, No.4., pp.313-331.

Pettit, S. and Taylor, D. (2007), "Humanitarian aid supply chain assessment: A preliminary consideration of the relevance of lean supply chain concepts to humanitarian aid supply chains”, In: Halldórsson, Á. and Stefánsson, G. (eds.): Proceedings of the 19th Annual Conference for Nordic Researchers in Logistics, NOFOMA 2007, Reykjavík, Iceland, pp.881-894.

Régnier, P., Neri, B., Scuteri, S. and Minati, S. (2008), "From emergency relief to livelihood recovery: lessons learned from post-tsunami experiences in Indonesia and India”, Disaster Prevention and Management, Vol.17 No.3, pp.410-429.

Sachan, A. and Datta, S. (2005), "Review of supply chain management and logistics research”, International Journal of Physical Distribution and Logistics Management, Vol.35 No.9, pp.664-705.

Safran, P. (2003), “A strategic approach for disaster and emergency assistance”, $5^{\text {th }}$ Asian Disaster Reduction Center International Meeting and the 2nd UN-ISDR Asian Meeting, 15-17 January 2003, Kobe, Japan. Available at www.adb.org/Documents/Policies?Disaster_Emergency/disaster_emergency.p df, (accessed 26 June 2006).

Schulz, S.F. and Heigh, I. (2009), "Logistics performance measurement in action within a humanitarian organization”, Management Research News, Vol.32 No.11, pp.1038-1049.

Slim, H. (2002), “Not philanthropy but rights”, International Journal of Human Rights, Vol.6 No.2, also available from the Overseas Development Institute at http://www.odi.org.uk/hpg/confpapers/slim_new.pdf, accessed Nov 15, 2009. 
Spens, K.M. and Bask, A.H. (2002), “Developing a framework for supply chain management”, International Journal of Logistics Management, Vol.13 No.1, pp.73-88.

Swinehart, K.D. and Smith, A.E. (2005), "Internal supply chain performance measurement: a health care continuous improvement implementation", International Journal of Health Care Quality Assurance, Vol.18 No.1, pp.533-542.

Tatham, P. (2009), "An investigation into the suitability of the use of unmanned aerial vehicles (UAVs) to support the initial needs assessment process in rapid onset humanitarian disasters”, International Journal of Risk Assessment and Management, Vol.13 No.1, pp.60-78.

Taylor, D. and Pettit, S. (2009), “A consideration of the relevance of lean supply chain concepts for humanitarian aid provision”, International Journal of Services Technology and Management, Vol.12 No.4, pp.430-444.

Tesfaye, A. (2007), "Problems and prospects of housing development in Ethiopia”, Property Management, Vol.25 No.1, pp.27-53.

Thomas, A. and Kopczak, L. (2005), "From logistics to supply chain management. The path forward in the humanitarian sector", Fritz Institute, available at: www.fritzinstitute.org/PDFs/WhitePaper/FromLogisticsto.pdf (accessed 25 Jan 2009).

Thomas, A. and Mizushima, M. (2005), “Logistics training: necessity or luxury?”, Forced Migration Review, No. 22, pp. 60-61.

Tomasini, R. and van Wassenhove, L. (2009), Humanitarian Logistics, INSEAD Business Press Series, Palgrave Macmillan, Basingstoke, UK.

Trunick, P.A. (2005), “Special report: delivering relief to tsunami victims”, Logistics Today, Vol.46, No.2, pp. 1-3.

van der Laan, E.A., de Brito, M.P. and Vergunst, D.A. (2009), "Performance measurement in humanitarian supply chains”, International Journal of Risk Assessment and Management, Vol.13 No.1, pp.22-45.

van Wassenhove, L.N. (2006), "Humanitarian aid logistics: supply chain management in high gear", Journal of the Operational Research Society, Vol.57 No.5, pp.475-489.

Wang, R., Sedransk, J. and Jinn, J.H. (1992), "Secondary data analysis when there are missing observations”, Journal of the American Statistical Association, Vol.87 No.420, pp.952-961.

Yam, H.K., Mercer, S.W., Wong, L.Y., Chan, W.K. and Yeoh, E.K. (2009), "Public and private healthcare services utilization by non-institutional elderly in Hong Kong: is the inverse care law operating?”, Health Policy, Vol.91 No.3, pp.229-238. 